\title{
1
}

\section{The Potential of Narrative and Experiential Approaches in Multicultural Inquiries}

\author{
JoAnn Phillion, Ming Fang He, \\ and F. Michael Connelly
}

$\mathrm{n}$ Narrative and Experience in Multicultural Education we explore the untapped potential that narrative and experiential approaches provide in understanding multicultural issues in education. We feature scholars whose work focuses on the lives of students, teachers, parents, and communities, while highlighting experiences seldom discussed in the literature. We believe that the experiential quality of this work is central to developing in-depth understanding of multicultural issues in education and in life.

As you read through this book, you will see that the authors bring personal experience to bear on their inquiries. You will see inquiry embedded in life and life embedded in constant change in relation to social, cultural, and political contexts. You will also be exposed to the ideas of self, others, and inquiry interrelated in complex and dialogical relationships over time and place. These scholars have developed their research questions, perspectives, and inquiry methods by drawing on what they care about passionately in life. Building upon their passion, these scholars engage themselves and others in a deeply reflective practice that has the possibility to transform everyday experience into insights with cultural, social, and educational significance. As demonstrated in each chapter, these scholars are not detached observers of, but active participants in, the lives of the people with whom they work. As they become immersed in the lives of their participants, they come to care deeply about their concerns and continuously search for effective ways to act on those concerns. 
The authors in this book are diverse; the inquiries they engage in are far ranging in terms of content, ethnic groups studied, and geographic locations. We, of course, could not feature the entire spectrum of the authors' work, and there were many multicultural education issues that we were unable to cover, such as special needs, sexual orientation, gender, and the experiences of other ethnic groups. We believe that the significance of bringing this particular work forward is that it provides a new way of understanding the nuances of multicultural life and the complexity of multicultural issues in education. The special quality of the work featured in this book that distinguishes it from other work in multicultural education is its emphasis on understanding experience and transforming this understanding into significant social and educational implications.

\section{Reading With an Experiential Eye and an Imaginative Eye}

The chapters in Narrative and Experience in Multicultural Education are concrete, detailed, and filled with specifics of multicultural life and multicultural education. The inquiries in the book open the door to other inquiries and suggest new methodological approaches to multicultural research that have potential to enrich and broaden the understanding of experience in multicultural societies. We hope that readers will vicariously experience the complex multicultural life portrayed by the authors and will recognize the global multicultural issues toward which these chapters turn our minds.

We invite readers to read the chapters with an experiential eye-seeing, hearing, and feeling the nuances of multicultural life and illuminating the details of experience brought forward in each of the studies. We encourage readers to vicariously travel with each author into the research site, imagining themselves in that setting and experiencing the lives of the participants. Through reading with an experiential eye, readers will not only see, hear, and feel the multicultural lives of those under study but also, in some small way, carry on the inquiries alongside the authors.

We also encourage readers to read with an imaginative eye, exploring broad multicultural themes that drive each author's work. The imaginative eye inspires readers to see "unexplored possibilities," to nurture "reflectiveness and expressiveness" (Greene, 2001) and to search for the meaning of experience. We want readers to understand the experiences of authors and participants, not in a predictable, fragmented, categorized sense, but in relation to their own experience and in relation to the historical, geographical, sociopolitical, cultural, and other contexts of the inquiries. We also encourage readers to challenge themselves to look beyond stereotypes, the familiar, and what they take for granted in order to recognize the complexity of multicultural lives. 
Reading with an experiential eye and an imaginative eye enables readers to deeply delve into the inquiries, to experience the passion and commitment of authors and participants, to puzzle over situations, to think about the meaning of the inquiries in relation to broader multicultural issues, and to envision possibilities for change in their own lives and the lives of those with whom they work. This method of reading a text can also be a method of reading the world. In addition, this method is a starting point for understanding narrative and experiential approaches to multicultural issues in education.

\section{Structure of the Book and Outline of Chapters}

Narrative and Experience in Multicultural Education is divided into six units. Three units address multicultural concerns of major North American ethnic groups-African Americans, Latinos/Latinas and Native Americans. One of the units focuses on international multicultural teacher education issues, and one unit is focused explicitly on narrative methodology in multicultural education research. The final unit addresses multiculturalism in democratic and community life. Chapters 2 through 14 contain an autobiographical introduction in which the authors connect the work presented in the chapter to their personal narrative histories. Each of these chapters concludes with further readings that were instrumental in the development of the authors' inquiry lines. Also at the end of each chapter, readers will find Reflective Questions that provide a starting point for discussion of the ideas in the chapter.

\section{UNIT ONE: PERSONAL NARRATIVE, COMMUNITY NARRATIVE, AND THE AFRICAN AMERICAN EXPERIENCE}

In Chapter 2, "Examining School-Community Connections Through Stories," Saundra Murray Nettles examines the emergence of a narrative that celebrates school and student strengths from a contrasting narrative, which characterized the school as deficient and harmful. She explores this school's narrative and the ways it changes using personal stories of two African American women - the principal and the author-and other information from the school community. The inquiry shows how interactions between the school community's narrative and the personal narrative of individuals contribute to the shaping and reshaping of a school's image. Nettles suggests that school-community connections in her research site contributed to a change in the context from one that was inconsistently supportive of student achievement to one that was consistently supportive.

In Chapter 3, "Black Women Writing Autobiography: Autobiography in Multicultural Education," Meta Harris examines Black women writing 
autobiography and how teachers and students can employ autobiographical writing to develop better interactions between teachers and students and between diverse students in multicultural education. Harris found that writing autobiography provides the opportunity not only to explore history from a personal perspective, relative to the political happenings of the times, local events, Black community events, academic experiences, and other occurrences that impact life, but also to revisit those times from a "removed" perspective. Harris also found that writing autobiography opens avenues for individuals to examine how personal and educational experience impacts who they are and how they perceive, react to, and interact with others in multicultural societies.

\section{UNIT TWO: LATINA/LATINO \\ COMMUNITIES, FAMILIES, AND CHILDREN}

In Chapter 4, "Being Educated in the Absence of Multiculturalism," Alma Rubal-Lopez and Angela Anselmo examine the experiences of two Latina Nuyorican sisters who were educated in the South Bronx (New York) during the 1950s and 1960s. Their narratives are used to recount their educational experiences in an oftentimes hostile and lonely environment. The authors compare what that experience was like and how it would be different today, and they address the role of multicultural education as a key factor in making that experience different.

In Chapter 5, "Between the Telling and the Told: Latina Mothers Negotiating Education in New Borderlands," Sofia Villenas discusses how Latina immigrant mothers face challenges in raising and schooling their bicultural children as they forge new communities in the United States. This chapter focuses on a conversation among Latina mothers, highlighting the spaces between the telling (the performances of dignity and strategic assertions of difference in the event of storytelling) and the told (the narrated events or descriptions supporting Latino family values and traditions). The women shared their struggles with assimilation, English language hegemony, bilingualism and biculturalism, the perils and necessity of doubling as working mothers in an unsupportive environment, and gendered ideologies about women's place in the home. These struggles reflected a process of teaching, learning, and negotiating life in new borderlands.

\section{UNIT THREE: SOCIAL JUSTICE, EQUALITY, AND THE EDUCATION OF NATIVE AMERICANS}

In Chapter 6, "White Teachers, Native Students: Rethinking Culture-Based Education," Mary Hermes discusses two White science teachers at tribal schools in the Upper Midwest of the United States. These teachers were identified by community members and school administrators as "successful" 
teachers. This chapter describes the experiences of these teachers as they wrestle with the daily effects of generations of oppression and poverty, as well as the beliefs and attitudes that help these teachers be effective allies and instructors for Native American students. Their experiences reveal the struggle with the contradictions of oppression, broaden the discussion of Native American culture-based education, and raise questions for the general applicability of cultural discontinuity as an explanation for Native American school failure.

In Chapter 7, "Journey Toward Social Justice: Curriculum Change and Educational Equity in a Navajo Community," Donna Deyhle provides a detailed narrative account of 20 years of participation in a school district with a large Navajo population. She documents the practical and policy struggles over the years to institute forms of schooling congenial to the Navajo community, and she describes the shifting imbalances between policy intentions and actual practices. In addition, she discusses how her role as researcher blends into that of community advocate and activist.

\section{UNIT FOUR: MULTICULTURAL TEACHER EDUCATION IN INTERNATIONAL CONTEXTS}

In Chapter 8, "Teachers as Transformative Healers: Struggles With the Complexities of the Democratic Sphere," Lourdes Diaz Soto presents narrative accounts of how teachers weave the post-September 11 World Trade Center tragedy into classroom curriculum to create transformative and healing spaces. These accounts demonstrate how issues of power became overwhelming and reveal that teachers' experience of this tragedy had emotional, intellectual, physical, and spiritual qualities. Soto depicts the complexities of the tragedy through teachers' working with young children as they struggled with the curriculum. This transformative process provided a space that enabled the researcher and the teachers to explore an education that moved beyond their current practice to one that was critically bilingual and multicultural.

In Chapter 9, How Is Education Possible When There's a Body in the Middle of the Room?, Freema Elbaz-Luwisch explores the possibility of multicultural and diverse education in Israel. Elbaz-Luwisch tells the story of her attempt to figure out what might be learned from the situation of Jewish Israelis and Arab/Palestinian Israelis living with violence, with threats to personal safety, and with death part of everyday life. She draws on experiences of dialogue between Jewish and Arab/Palestinian Israelis in preservice and inservice settings at the University of Haifa to suggest that attention to feelings-to the expression of fear, vulnerability, and anger - and to the body, which carries these feelings and experiences, is needed in order to make such dialogue possible.

In Chapter 10, "Multicultural Perspectives in Teacher Development," Grace Feuerverger focuses on her experience of teaching a multicultural teacher education class. Feuerverger and her students inquired into the 
meaning of self in a multicultural context that invited collective stories of dislocation, survival, and triumph over adversity. She confronted her own multiple cultural identities, her sense of being on the margins, and her psychological "orphanhood" as a child of Holocaust survivors. She created a classroom as a site of cultural encounters and networks of personal and professional negotiations and as a means to explore issues of diversity and difference. Through an exploration of the relationship between personal and professional lives, Feuerverger creates a nuanced pedagogical discourse of intercultural understanding and harmony that stands as a moral and ethical challenge in the study of multicultural education.

\section{UNIT FIVE: NARRATIVE INQUIRY \\ IN MULTICULTURAL EDUCATION}

In Chapter 11, “The World in My Text: A Quest for Pluralism," Carola Conle examines the idea of cultural pluralism as expressed in 10 years of her academic writing. Searching for tensions, subtexts, and implicit agendas, Conle recognizes underlying issues important in cultural pluralism: reflection within encounters of difference, recognition, public spaces for social self-reflection, and discursive practices conducive to inquiry. She explores the conditions within which human beings safeguard their identity. Her narrative inquiry has developed in a congenial space where different experiences were heard and valued. Conle discusses how inquiry flourishes in pluralistic societies.

In Chapter 12, "The Art of Narrative Inquiry: Embracing Emotion and Seeing Transformation," Chris Liska Carger explores the experiences of a Mexican American immigrant family. Using narrative inquiry, she studied a Latino high school dropout and his family's struggles to become American citizens. She discusses narrative inquiry and the potential of this method to help teachers and researchers to understand diverse students' backgrounds and the implications of their experiences for education. Carger concludes that, for her, research is more than an academic exercise; rather, it is a form of social action.

\section{UNIT SIX: DEMOCRACY, SCHOOL LIFE, AND \\ COMMUNITY IN MULTICULTURAL SOCIETIES}

In Chapter 13, "Narrative Inquiry Into Multicultural Life in an Inner-City Community School," F. Michael Connelly, JoAnn Phillion, and Ming Fang He explore the connection between multicultural education and narrative inquiry in Canadian social life. They trace 20 years of narrative inquiry in a Canadian inner-city school and argue that an understanding of multicultural life as a 
democratic life process is central to an understanding of the social purposes of multiculturalism. They believe that multicultural education and narrative inquiry have the potential for profoundly productive links in the pursuit of democratic life.

In Chapter 14, "Creating Communities of Cultural Imagination: Negotiating a Curriculum of Diversity," Janice Huber, M. Shaun Murphy, and D. Jean Clandinin inquire into the making of a diverse curriculum by attending to children's stories, teachers' stories, and stories of school. They focus on a particular curriculum space, peace candle gatherings, as the site for attending to the stories. The stories were collected in two classroom settings in Western Canada, an inner-city Grade 3-4 and a rural Grade 1. The authors examine the shaping influence of cultural stories and stories of school on curriculum.

In Chapter 15, "Narrative and Experiential Approaches to Multiculturalism in Education: Democracy and Education," Ming Fang He, JoAnn Phillion, and F. Michael Connelly borrow Dewey's key concepts-democracy and education-to conclude the book. They point out that a democratic vision, one of justice and equality for all, permeates the book. They believe that this vision, with equality and justice not only as catchwords but as genuine possibilities, is a vision of multicultural democratic life. They also discuss potentials and concerns of narrative and experiential approaches to the study of multicultural issues in education.

\section{Multiculturalism Across Disciplines and in Education}

As you go through each chapter with an experiential eye and an imaginative eye, we would like you to travel with us to explore some background that we think is relevant to a narrative, experiential approach to multiculturalism. Multiculturalism has become the key educational issue of our epoch. It permeates the discourse of many disciplines and has transformed thinking in many fields (Kalantzis \& Cope, 1992). In the field of political science, multiculturalism in Europe, Canada, and the United States is increasingly linked to controversial discussions of democracy in global contexts (e.g., Dyer, 1996). Multiculturalism is of major concern in philosophical debates about cultivating human potential in a global context (e.g., Nussbaum, 1997), expanding notions of community to create spaces for genuine encounters among different people to reach common goals (e.g., Greene, 1993), and understanding the complex, changing nature of contemporary cultural and individual identity (e.g., Taylor, 1994). In women's studies, scholars are using multiculturalism as a lens to understand and critique gender and class issues and to expand women's epistemologies (e.g., Golberger, Tarule, Clinchy \& Belenky, 1996). According to Sue, Ivey, and Pederson (1996), 
the impact of multiculturalism in psychology is so strong that it has changed the entire discipline, and they describe this approach as the "fourth wave," after psychoanalytic, behaviorist, and humanist approaches.

No discipline is more profoundly affected by multiculturalism than education. Multiculturalism permeates all levels of education, from universities to public schools. In higher education, prominent universities have created centers, such as Princeton University's Center for Human Values, founded in 1991, to support teaching, research, and public discussion of fundamental questions related to diversity that span academic disciplines (Gutmann, 1994). Many universities have established cross-disciplinary courses on multiculturalism that fulfill undergraduate degree requirements (Nussbaum, 1997). Universities throughout the United States are engaged in preparing teachers and university professors to be multicultural educators.

In public school education, the interest in multicultural education relates to school practice (e.g., Banks \& Banks, 1989; Cummins, 1989; Gay, 2000; Howard, 1999; Ladson-Billings, 1994; Nieto, 2000) and to scholarship and research (Banks \& Banks, 2004). In elementary and secondary schooling, there is a rethinking at the policy level taking place in response to changes in societies, in particular in response to changing student demographics, especially in urban areas (Dentler \& Hafner, 1997). There is also progressively more awareness of multicultural issues in areas not traditionally thought of as "needing" multicultural education, especially in rural areas (Yeo, 1999) and in predominantly White areas (Glazer, 1997).

Influential professional bodies, such as the American Association of Colleges for Teacher Education, the Association for Supervision and Curriculum Development, and the National Education Association, published policy statements on multicultural education as early as the 1970s (Gay, 1995). The National Council for the Accreditation of Teacher Education mandates that issues of diversity be integrated in teacher education in order for institutions to be accredited (NCATE, 2001). Educational bodies such as the American Educational Research Association have made issues of diversity of paramount importance (AERA, 1997).

One of the major shifts in multicultural education is the increasing recognition that multiculturalism has become a global issue rather than solely a North American issue (e.g., Grant \& Lei, 2001; Moodley, 1992). Another shift is a move beyond Black and White issues to the inclusion of a diversity of ethnic and cultural groups (e.g., Seller \& Weis, 1997; Wu, 2002). There is also a shift from demographic and population studies, combined with prescriptive action to be taken by policymakers and local educators, to studies such as those featured in this book-in-depth studies of the quality of multicultural life in communities, schools, and families (see also Soto, 1997; Valdés, 1996; Vasquez, Pease-Alvarez, \& Shannon, 1994). 


\section{A Turn to Narrative and Experience}

As you continue to explore background relevant to narrative and experiential approaches to multiculturalism, we encourage you to look deeply into the methodological approaches used in the inquiries in this book. Parallel with the increasing interest in multiculturalism, there has been a movement toward developing methods appropriate for the understanding of multicultural phenomena previously only explored from a Western scientific perspective. This perspective has limited understanding of multicultural issues (Sue, 1999). There is, however, a new wave of thinking in the field of educational research that challenges the Western scientific perspective. It has been called the "sixth moment" (Denzin, 1997), a time of questioning whose knowledge should be considered valid and a time when research participants have their own ideas about how their experiences should be interpreted, theorized, and represented. Many researchers have searched for ways to respond to the sixth moment. There are some researchers who have developed approaches to multiculturalism in education that focus on in-depth understanding of diverse experiences of individuals, families, and communities. Much of that work has been done by women, many are ethnographers, some are narrative inquirers, many are from the same ethnic background as the people with whom they work, many are fluent in the languages of the communities in which they live and study, and many advocate on behalf of students, parents, and communities (e.g., Carger, 1996; Feuerverger, 2001; Soto, 1997; Valdés, 1996). Another major response to the sixth moment is a turn toward narrative, which Denzin and Lincoln (2003) call the "seventh moment." In addition, the use of narrative is in response to recognition of the complexity of human experience in increasingly diversified societies. In a broad sense, this book reflects the seventh moment in that it focuses on the study of experience in multiculturalism in education.

We call this study of experience narrative inquiry (Clandinin \& Connelly, 2000), the specific focus on multicultural experience narrative multiculturalism (Phillion, 2002d), and the specific focus on cross-cultural experience crosscultural narrative inquiry (He, 2003). Connelly and Clandinin (1988, 1990; Clandinin \& Connelly, 1994, 2000) were among the first to bring an experiential focus to educational research. People from different educational fields are beginning to incorporate experiential aspects into inquiries regarding multicultural issues in education: for instance, Bell (1997), Carger (1996), and Valdés (1996) in language and culture issues; Ayers (2001), Foster (1997), and Sleeter (2001) in teacher narrative; Feuerverger (2001) and Soto (1997) in family and community narrative; Elbaz-Luwisch (1997), Hollingsworth (1994), and Phillion (1999, 2002a, 2002b, 2002c, 2002d) in multicultural teaching and learning; Conle (2000) and He (1999, 2002a, 2002b, 2002c, 2003, in press) in cross-cultural issues; and hooks $(1991,2000)$ in race, gender, and class issues. 
One aspect of these inquiries is the idea of understanding experience in its own terms rather than categorizing experience according to predetermined structures and theories (Phillion, 1999). Many of these inquiries are "peopled" with characters rather than filled with categories and labels. Another aspect of these inquiries is the inquirer's recognition of sociopolitical and cultural contexts in shaping experience. The inherent potential of these inquiries lies in the possibility of effecting social change beginning with the individual and expanding into the greater community.

As narrative inquirers with strong interests in the lives of people living in diverse contexts, we feel that this kind of in-depth exploration that focuses on an understanding of experience, rather than on elaborating predetermined categories derived from theory, holds promise for ways to think about long-standing multicultural issues in global contexts. The chapters in this book contribute in this way to the history of work in multicultural education by examining issues through a more personal lens: the authors are committed to the participants in their inquiry and to the hope that the research will better participants' lives. The work illuminates and addresses structural inequalities in ways that bring life to issues that make them impossible to ignore. Researchers engaged in this work often take an active political stance, and many of the projects are directly aimed at making social and educational change. Although many of the authors would not describe themselves as being in multicultural education, we nevertheless find that these chapters illuminate multicultural issues. These are exciting chapters that tell us what it is like to do research at the "seventh moment" and give us a strong sense of what a turn to narrative and experience means in the study of multiculturalism in education.

Work featured in Narrative and Experience in Multicultural Education, embedded in lives and communities on the one hand and powerful ideas of being human on the other hand, is at the heart of narrative and experiential approaches to multiculturalism. As you go through the chapters with an experiential eye and an imaginative eye, we hope you will discover the particular qualities of these inquiries and the potential of narrative and experiential approaches to develop in-depth, nuanced understandings of multicultural issues in education. We also hope that this understanding will be transformed into hope and the possibility for better, more equitable lives in multicultural societies.

\section{Recommended Readings}

We would like to introduce readers who are not familiar with it to the theory of experience literature, in particular Dewey's work in Education and Experience 
(1938), and to Schwab's theory of the practical (Westbury \& Wilkof, 1978). The work of Dewey and Schwab draws attention to the experiential aspect of multicultural issues and to the potential of understanding experience to affect social and educational change.

Readers can also delve into related work in anthropology, such as Bateson (1994), Behar (1996), and Geertz (1995). This type of work enables readers to see culture as changing, fluid, and dynamic and multicultural inquiry as personal and embedded in history and place.

Exploring writing in philosophy on narrative imagination (Greene, 1995; Nussbaum, 1997) and notions of identity in pluralistic societies (Taylor, 1989) will help readers develop the ability to empathize with others, to perceive themselves not only as members of local communities but also as members of a world community, and to create possibilities for better lives in multicultural societies. These qualities are central to an understanding of narrative and experiential approaches to multiculturalism in education.

Readers might also benefit from exploring life-based literary narratives that focus on language, culture, and identity issues in real-life contexts. In particular, work such as Chamoiseau (1994) and Hoffman (1989) helps develop an in-depth understanding of lived experience from the perspective of participants. We believe that life-based literary narratives bring experiential qualities to multicultural theories and foster the development of narrative imagination-the ability to reflect on experience, question assumptions, and actively empathize with others (Phillion \& He, 2005).

\section{References}

American Educational Research Association. (1997). Report from the task force on the role and future of minorities. Washington, DC: Author.

Ayers, W. C. (2001). To teach: The journey of a teacher. New York: Teachers College Press.

Banks, J. A., \& Banks, C. A. M. (Eds.). (1989). Multicultural education: Issues and perspectives. Needham Heights, MA: Simon \& Schuster.

Banks, J. A., \& Banks, C. A. M. (Eds.). (2004). Handbook of research on multicultural education (2nd ed.). San Francisco: Jossey-Bass.

Bateson, M. C. (1994). Peripheral visions: Learning along the way. New York: HarperCollins.

Behar, R. (1996). The vulnerable observer: Anthropology that breaks your heart. Boston: Beacon Press.

Bell, J. S. (1997). Literacy, culture, and identity. New York: Peter Lang.

Carger, C. (1996). Of borders and dreams: Mexican-American experience of urban education. New York: Teachers College Press.

Chamoiseau, P. (1994). School days. Lincoln: University of Nebraska Press.

Clandinin, D. J., \& Connelly, F. M. (1994). Personal experience methods. In N. K. Denin and Y. S. Lincoln (Eds.), Handbook of qualitative research (pp. 413-427). Thousand Oaks, CA: Sage. 


\section{NARRATIVE AND EXPERIENCE IN MULTICULTURAL EDUCATION}

Clandinin, D. J., \& Connelly, F. M. (2000). Narrative inquiry: Experience and story in qualitative research. San Francisco: Jossey-Bass.

Conle, C. (2000). Thesis as narrative: What is the inquiry in narrative inquiry? Curriculum Inquiry, 30(2), 189-213.

Connelly, F. M., \& Clandinin, D. J. (1988). Teachers as curriculum planners: Narratives of experience. New York: Teachers College Press.

Connelly, F. M., \& Clandinin, D. J. (1990). Stories of experience and narrative inquiry. Educational Researcher, 19(5), 2-14.

Cummins, J. (1989). Empowering minority students. Sacramento: California Association for Bilingual Education.

Dentler, R. A., \& Hafner, A. L. (1997). Hosting newcomers: Structuring educational opportunities for immigrant children. New York: Teachers College Press.

Denzin, N. K. (1997). Interpretive ethnography: Ethnographic practices for the 21st century. Thousand Oaks, CA: Sage.

Denzin, N., \& Lincoln, Y. (2003). The landscape of qualitative research: Theories and issues (2nd ed.). Thousand Oaks, CA: Sage.

Dewey, J. (1938). Experience and education. New York: Collier Books.

Dyer, G. (1996). Millennium. Toronto: Canadian Broadcasting Corporation.

Elbaz-Luwisch, F. (1997). Narrative research: Political issues and implications. Teaching and Teacher Education, 13(1), 75-83.

Feuerverger, G. (2001). Oasis of dreams: Teaching and learning peace in a JewishPalestinian village in Israel. New York: RoutledgeFalmer.

Foster, M. (1997). Black teachers on teaching. New York: New Press.

Gay, G. (1995). Bridging multicultural theory and practice. Multicultural Education, $3(1), 4-9$.

Gay, G. (2000). Culturally responsive teaching: Theory, research, and practice. New York: Teachers College Press.

Geertz, C. (1995). After the fact: Two countries, four decades, one anthropologist. Cambridge, MA: Harvard University Press.

Glazer, N. (1997). We are all multiculturalists now. Cambridge, MA: Harvard University Press.

Goldberger, N., Tarule, J., Clinchy, B., \& Belenky, M. (1996). Knowledge, difference and power. New York: Basic Books.

Grant, C., \& Lei, J. L. (Eds.). (2001). Global constructions of multicultural education: Theories and realities. Mahwah, NJ: Lawrence Erlbaum.

Greene, M. (1993). The passions of pluralism: Multiculturalism and the expanding community. Educational Researcher, 22(1), 13-18.

Greene, M. (1995). Releasing the imagination: Essays on education, the arts, and social change. San Francisco: Jossey-Bass.

Greene, M. (2001). Variations on a blue guitar: The Lincoln Center Institute lectures on aesthetic education. New York: Teachers College Press.

Gutmann, A. (Ed.). (1994). Multiculturalism: Examining the politics of recognition. Princeton, NJ: Princeton University Press.

He, M. F. (1999). A life-long inquiry forever flowing between China and Canada: Crafting a composite auto/biographic narrative method to represent three Chinese women teachers' cultural experiences (Featured article). Journal of Critical Inquiry Into Curriculum \& Instruction, 1(2), 5-29. 
He, M. F. (2002a). A narrative inquiry of cross-cultural lives: Lives in Canada. Journal of Curriculum Studies, 34(3), 323-342.

He, M. F. (2002b). A narrative inquiry of cross-cultural lives: Lives in China. Journal of Curriculum Studies, 34(3), 301-321.

He, M. F. (2002c). A narrative inquiry of cross-cultural lives: Lives in North American Academe. Journal of Curriculum Studies, 34(5), 513-533.

He, M. F. (2003). A river forever flowing: Cross-cultural lives and identities in the multicultural landscape. Greenwich, CT: Information Age.

He, M. F. (in press). In-between China and North America. In T. R. Berry \& N. D. Mizelle (Eds.), From oppression to grace: Women of color and their dilemmas within the academy. Sterling, VA: Stylus.

Hoffman, E. (1989). Lost in translation: A life in a new language. New York: Penguin Books.

Hollingsworth, S. (1994). Teacher research and urban literacy education: Lessons and conversations in a feminist key. New York: Teachers College Press.

hooks, b. (1991). Narratives of struggle. In P. Mariani (Ed.), Critical fictions: The politics of imaginative writing (pp. 53-61). Seattle, WA: Bay.

hooks, b. (2000). Where we stand: Class matters. New York: Routledge.

Howard, G. R. (1999). We can't teach what we don't know: White teachers, multiracial schools. New York: Teachers College Press.

Kalantzis, M., \& Cope, W. (1992, November 4). Multiculturalism may prove to be the key issue of our epoch. The Chronicle of Higher Education, pp. B3, B5.

Ladson-Billings, G. (1994). The dream keepers: Successful teachers of African American children. San Francisco: Jossey-Bass.

Moodley, K. A. (Ed.). (1992). Beyond multicultural education: International perspectives. Calgary, Alberta: Detselig Enterprises.

National Council for the Accreditation of Teacher Education. (2001). Professional standards for the accreditation of schools, colleges, and departments of education. Washington, DC: Author.

Nieto, S. (2000). Affirming diversity: The sociopolitical context of multicultural education (2nd ed.). New York: Longman.

Nussbaum, M. (1997). Cultivating humanity: A classical defense of reform in liberal education. Cambridge, MA: Harvard University Press.

Phillion, J. (1999). Narrative and formalistic approaches to the study of multiculturalism. Curriculum Inquiry, 29(1), 129-141.

Phillion, J. (2002a). Becoming a narrative inquirer in a multicultural landscape. Journal of Curriculum Studies, 34(5), 535-556.

Phillion, J. (2002b). Classroom stories of multicultural teaching and learning. Journal of Curriculum Studies, 34(3), 281-300.

Phillion, J. (2002c). Narrative inquiry in a multicultural landscape: Multicultural teaching and learning. Westport, CT: Ablex.

Phillion, J. (2002d). Narrative multiculturalism. Journal of Curriculum Studies, 34(3), 265-279.

Phillion, J., \& He, M. F. (2005). Narrative inquiry and ELT research. In J. Cummins \& C. Davison (Eds.), The international handbook of English language teaching (Vol. 2). Norwell, MA: Springer (formerly Kluwer Academic Publishers).

Seller, M., \& Weis, L. (1997). Beyond Black and White: New faces and voices in U.S. schools. Albany: SUNY Press. 


\section{NARRATIVE AND EXPERIENCE IN MULTICULTURAL EDUCATION}

Sleeter, C. E. (2001). Epistemological diversity in research on preservice teacher preparation for historically underserved children. In W. G. Secada (Ed.), Review of research in education (Vol. 25, pp. 209-250). Washington, DC: American Educational Research Association.

Soto, L. D. (1997). Language, culture, and power: Bilingual families and the struggle for quality education. Albany: SUNY Press.

Sue, S. (1999). Science, ethnicity, and bias. American Psychologist, 54(12), 1070-1077.

Sue, D. W., Ivey, A. E., \& Pederson, P. B. (1996). A theory of multicultural counseling and therapy. Pacific Grove, CA: Brooks/Cole.

Taylor, C. (1989). Sources of the self: The making of the modern identity. Cambridge, MA: Harvard University Press.

Taylor, C. (1994). The politics of recognition. In A. Gutmann (Ed.), Multiculturalism: Examining the politics of recognition (pp. 25-73). Princeton, NJ: Princeton University Press.

Valdés, G. (1996). Con respeto: Bridging the distances between culturally diverse families and schools. New York: Teachers College Press.

Vasquez, O. A., Pease-Alvarez, L., \& Shannon, S. M. (1994). Pushing boundaries: Language and culture in a Mexicano community. New York: Press Syndicate of the University of Cambridge.

Westbury, I., \& Wilkof, N. J. (Eds.). (1978). Science, curriculum, and liberal education: Selected essays: Joseph J. Schwab. Chicago: University of Chicago Press.

Wu, F. H. (2002). Yellow: Race in America beyond Black and White. New York: Basic Books.

Yeo, F. (1999). The barriers of diversity: Multicultural education and rural schools. Multicultural Education, 7(1), 1-7. 